\section{Exfoliated epithelial cells: potentials to explore gastrointestinal maturation of preterm infants}

\section{Células epiteliais exfoliadas: potencial para investigar a maturação gastrointestinal em crianças pré-termo}

Bertrand Kaeffer ${ }^{1}$

1 UMR 1280 Phan, INRA and University of Nantes, CHU - Hôtel DIEU HNB1, Place Alexis Ricordeau 44093 Nantes Cedex 1 (France, EU).

E-mail: Bertrand.Kaeffer@univ-nantes.fr

\begin{abstract}
Exfoliated epithelial cells represent valuable source of information on the physiopathological state of the mucosa. However, the interpretation of data obtained from exfoliated cells is complicated by the conditions of isolation as well as the health of the subject. Exfoliation is either: a) a natural loss of body cells implying a molecular signal related to the turnover of terminally differentiated cells and to the progressive mobilization of proliferative as well as stem cells or $b$ ) the result of manual exfoliation by applying mechanical constraints like scraping. Depending on the methodology of isolation, exfoliated epithelial cells are believed to be either in apoptosis or in anoïkis. Most studies are using microscopic examination to demonstrate the presence of typical cells along with measurements on a limited number of biomarkers. Only few studies using proteomics or transcriptomics are available and they open discussion about tissue references and normalization. The main advantage of measures realized on exfoliated epithelial cells is that they are strictly non-invasive and open the possibility to evaluate maturation of gastric and intestinal tissues in long-term experiments performed on the same animal or in translational research on samples recovered from preterm infants.
\end{abstract}

Key words Mammals, Biological clocks, Gut, Neonate, Premature, Epithelial cells

\section{Resumo}

Células epiteliais exfoliadas são uma fonte de informação valiosa sobre o estado fisiológico da mucosa. Contudo, a interpretação dos dados obtidos de células exfoliadas é complicado pelas condições de isolamento e da saúde do sujeito. A exfoliação é: a) uma perda natural de células implicando um sinal molecular relacionado ao turnover terminal de células diferenciadas e à progressiva mobilização de células proliferativas e de células tronco ou b) o resultado de aplicação de fatores mecânicos como raspagem. Dependendo do método de islolamento, acredita-se que podem estar em apoptose ou em anoikis. A maior parte dos estudos tem utilizado exame microscópico para demonstrar a presença de células típicas com medições sobre um número limitado de biomarcadores. Apenas uns poucos estudos usando proteômica ou transcriptômica estão disponiveis e discutem sobre referenciais de tecidos e normalização. A principal vantagem de medidas realizadas em células epiteliais exfoliadas é que elas são estritamente não invasivas e abertas à possibilidade de avaliar a maturação de tecidos gástricos e intestinais em experimentos de longo prazo feitos no mesmo animal ou em pesquisas translacionais com amostras obtidas de crianças pré-termo

Palavras-chave Mamíferos, Relógio biológico, Intestino, Neonato, Prematuro, Células epiteliais 


\section{Introduction}

Exfoliated or sloughed epithelial cells are naturally lost by mammals in their environment. These cells represent valuable tools for the study of the epithelial cell physiology of the mucosa and for predicting the outcome of nutritional/clinical intervention studies. Recovery of exfoliated cells from biological fluids is a non-invasive technology which is in high demand in the field of translational research as well as during long-term experiments designed to minimize the sacrifice of long-lived or precious animals. Exfoliated epithelial cells can be used as a surrogate for tissue biopsies in predicting changes in gene expression, DNA methylation, DNA damage, protein expression and the accumulation of dietary components 1,2 or in studying the expression of the circadian clock components. ${ }^{3}$ In the past, the recovery of cellular material from blood samples or tissue biopsies has been crucial in demonstrating the circadian nature of 180 biological parameters as well as the ultradian or seasonal rhythms of many others, 4-6 thereby sustaining the concept of reactive homeostasis. ${ }^{7}$ However, there are clear clinical histochemical limitations to biopsies or organ explants. The detection of clock gene products through biopsies of oral mucosa, 8 skin 8,9 or colon 10 cannot be used for long-term nutritional/intervention studies. Moreover studies of chrononutrition or chronopharmacology need to go beyond the relatively simple detection of molecules coded in the presence or absence of clock components. Investigators would like to be able to measure, at least, the difference between morning and evening parameters. Preferably, they wish to measure clock gene expression over at least three consecutive circadian cycles every 1-4 hours. Recent developments in the concept of epithelial homeostasis and the role of exfoliation in preserving epithelial architecture ${ }^{11}$ should be reevaluated to enable the use of these cells in neonatalogy to investigate gastrointestinal maturation. In addition, methodological improvements have been achieved in the efficient recovery of exfoliated epithelial cells, thereby allowing circadian clock molecular components to be recorded in situation where biological fluids can be collected regularly enough over time.

This review presents new concepts in the understanding of exfoliation and the influence of methodology on the isolation of exfoliated epithelial cell phenotypes, and, finally, speculates on the stability of biological information in such cellular material with a special emphasis on the regulation of peripheral circadian clocks.
Exfoliation is either a natural process to preserve tissue architecture or the result of external mechanical constraints

Exfoliation is a loss of cellular material retaining the basic cytological features of typical cells (plasma membrane, cytoplasm and nucleus). Exfoliated epithelial cells can be obtained from a wide range of the mucosae which line body passages and cavities communicating directly or indirectly with the exterior, such as mammary glands, oral, bronchial, urothelial or gastrointestinal epithelia. From a histological point of view, epithelia are organized into functional units containing different cellular compartments (stem, proliferative, mature or functional and senescent). These functional units are always at the interface with the environment. Epithelia can be divided into simple cylindrical cell monolayers, as in the case of the colon, or pseudostratified layers, as in the case of the urothelium. 12 At a given time point, a mucosal epithelium is supposed to lose different categories of cells by way of various exfoliation mechanisms (Figure 1). However, cell turn-over is driven by a delicate balance between cell loss and proliferation. Proliferation depends on two cellular compartments, proliferative cells capable of rapid mitosis to increase tissue regeneration and stem cells, which give rise to all phenotypes by way of assymetric mitosis. The speed of mitosis in proliferative compartment depends on cellular loss at the top of the structure and on tightly regulated cell migration along the functional units. 13,14 Cell migration in the small and large bowel of mice shows a strong circadian rhythm, with cell velocity reaching a peak at 9 a.m. and a minimum at 5 p.m. 15 Other rhythms which could be controlled by circadian clocks have been observed in the intestine, such as cell proliferation 16,17 or apoptosis. 18 Cell proliferation is also believed to be controlled by clockwork, not only in hepatocytes, 19 but also throughout the rat's gut. ${ }^{20}$ Seasonal proliferation rhythms have been described in adult rats by Haus et al., ${ }^{21}$ and Gomes et al. ${ }^{22}$ Circadian as well as seasonal cell proliferation rhythms are clearly relevant to the recovery of exfoliated quiescent cells holding specific and functional biomarkers (Figure 1).

\section{Exfoliation and the epithelium homeostasis}

Exfoliation has been described as an active biochemical process linked to epithelial homeostasis.3,23,24 It is believed that epithelial cells, losing contact with companion cells (such as fibroblasts) as well as the extracellular matrix, enter anoikis. 25 The detachment of epithelial cells triggers 


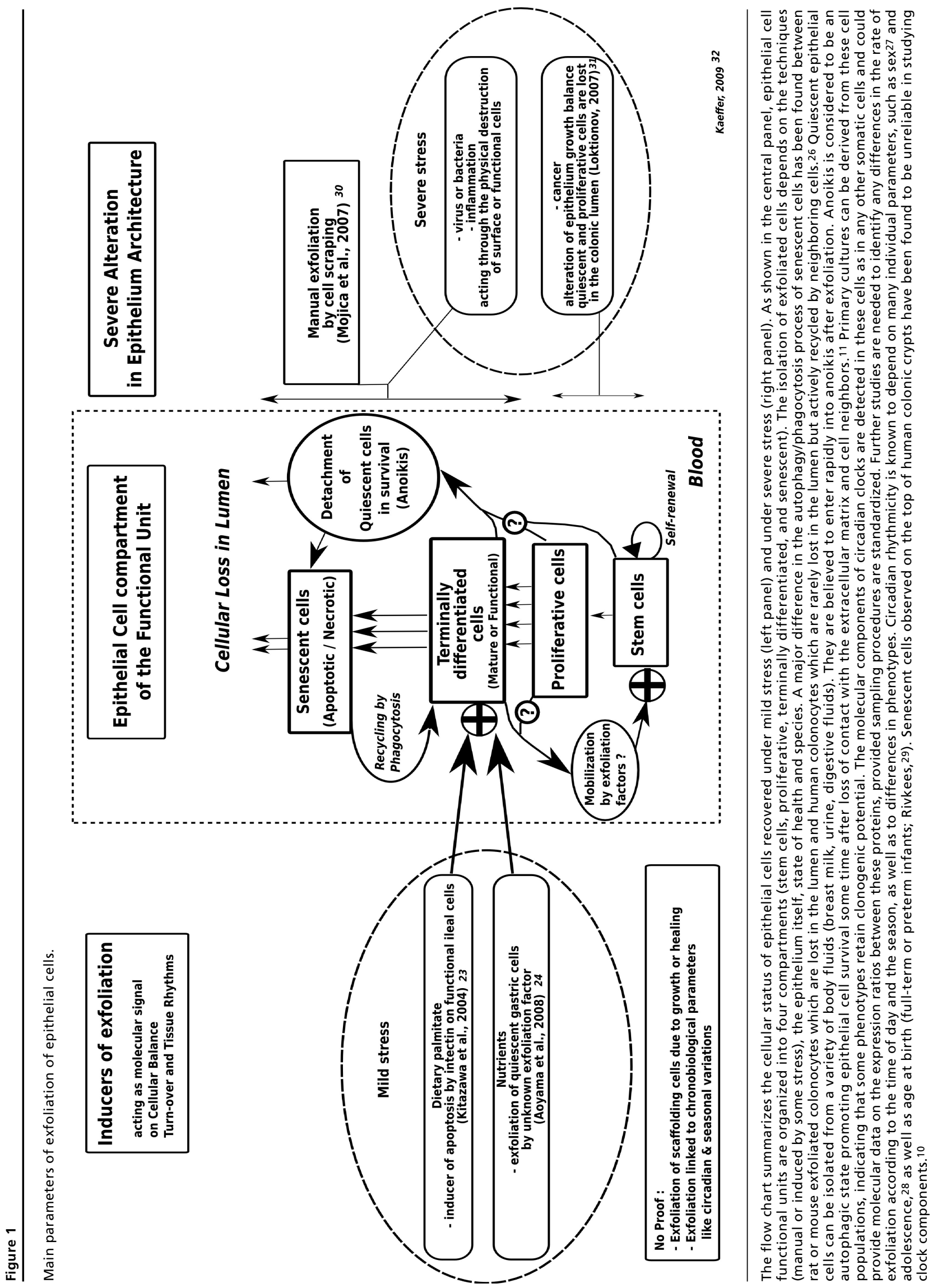


both pro- and anti-apoptotic signals, such as nuclear factor kappa-B, and inhibits the apoptosis protein family members. These anti-apoptotic mechanisms presumably delay the onset of apoptosis and allow cells to survive.33-35 The balance between these signals and the duration of detachment determine the subsequent fate of these cells. Anti-apoptotic signals presumably delay the onset of anoikis, allowing cells to survive, provided that they can reestablish extracellular matrix contact in time. ${ }^{11}$ Loss of extracellular matrix contact induces autophagy in normal epithelial cells and autophagy allows for the survival of detached cells during both anoikis and lumen formation in a $3 \mathrm{D}$ epithelial cell culture. 36,37 Given these assumptions, exfoliation may be understood as a natural process of removal of external cells from the luminal surface of an epithelium. Consequently, exfoliation has a physiological role to play in the architecture of the epithelium by allowing the formation of a lumen and presumably providing sufficient flexibility to preserve the physical integrity of the epithelium and enable it to grow. In three-dimensional epithelial cell cultures, both autophagy and apoptosis are observed during lumen formation. 36,37 By losing contact with the original mucosa, exfoliated epithelial cells activate autophagy as a survival mechanism to endure starvation. Starving cells break down cytoplasmic material to generate both nutrients and energy. 38 Quiescent exfoliated epithelial cells with no signs of apoptosis can be recovered under specific conditions in aspirated gastric fluid 3 or, by suction, from breast glands 39,40 or extensive rinsing at the end of routine colonoscopy.41 Many quiescent exfoliated epithelial cells can be cultured, suggesting that detachment-induced autophagy contributes to the viability of these cells. Human mammary epithelial cells die after 24-48 hours after detachment, while certain epithelial cells, in particular the primary mammary epithelial cells of mice and the intestinal epithelial cells of rats, perish within a few hours following substratum detachment. 13,37

Animal models have been developed to study the effect of cycles of nutrient intake on the exfoliation of epithelial cells in the digestive lumen. In adult rats that have fasted for 24 hours and subsequently fed for one hour, food intake induces exfoliation of quiescent parietal cells at the top of the gastric gland by way of an unidentified exfoliation factor. ${ }^{24}$ Under these conditions, stem cells located in the neck region of the gastric glands are believed to be actively recruited to repopulate the surface of the stomach of the adult rat. By contrast, in adult laboratory mice, fatty acids (such as palmitate) are inducers of intectine, a protein involved in the exfoliation of apoptotic cells at the top of the villi of the small intestine within one hour after feeding. ${ }^{23}$ These models that manipulate nutrition in order to induce exfoliation in the small intestine of mice ${ }^{23}$ or the gastric mucosa of rats 24 indicate that the exfoliation mechanism is highly context-dependent but they also suggest that it would be possible to develop in vivo studies of anoikis and autophagy in relation to the functioning of peripheral circadian clocks.

\section{Exfoliation by applying mechanical constraints}

In its simplest form, exfoliation is a loss of cells in the environment due to external mechanical forces, such as brushing or friction. Such forces have a deep effect on the epithelium architecture but rapidly yield high quantities of so-called normal epithelial cells. Manual exfoliation involves the brushing or scraping of the oral epithelium of the cheek or tongue; 42 cervical 43 or rectal swabbings 31 ; the obtaining of epithelial cells of the respiratory tract from sputum and oral mucosal cells by rinsing the mouth or chewing-gum (betel chewers 44 ), the obtaining of esophageal cells, 45 of mammary cells by way of nipple aspiration, from ductal lavage, 39 breast milk 40 or by obtaining bladder urothelial cells present in urine samples. 46,47 Manual exfoliation has also been proposed as a way of recovering intact, normal epithelial cells in tissue biopsies carried on the occasion of colon resection. 30,48 This technique partially purifies the cell preparation by taking advantage of the cell's inherent biology. Epithelial cells remain in small clumps or sheets, detached from any stromal elements that may have been scraped off. 48 This observation also holds true for gastric epithelial cells. ${ }^{3}$ The recovery of mechanically exfoliated cells by gentle swabbing can be used to obtain typical epithelial cells that are immediately available for analysis and may represent a reliable alternative to the oral mucosal punch biopsies of Bjarnason et al. ${ }^{8}$ in the study of clock gene variations in time series studies involving human volunteers.

In short, exfoliation is a broad term covering many different biological or experimental situations. There is still no proof that the exfoliation of quiescent cells follows a circadian rhythm. This is probably because the set of physiological parameters leading to active exfoliation are difficult to handle and the interpretation of data obtained from manual exfoliation is also highly context-sensitive. The next section will illustrate that the methods used to recover exfoliated cells are of paramount importance. 


\section{Methods for studying exfoliated cells}

A major difficulty with the use of exfoliated cells is finding a device or a method that allows for reliable and easy recovery of cell material. Moreover, for successful chronobiological studies, experimenters need to perform sampling with sufficient regularity over time and to take legal considerations into account. 49

\section{Handling of samples and cell isolation}

The best strategy is to avoid sample storage by performing cell isolation immediately on fresh samples. However, this is highly demanding in terms of time and manpower. It is common to store samples at $-70^{\circ} \mathrm{C}$ (for a maximum of six months). But, the gold standard is to use unfixed snap frozen exfoliated cells. 30 Alternatively, for isolation of freshly exfoliated cells subsequent to exposure to some inducers with the corresponding original epithelium, cryogenics needs to be used.24 Exfoliated cells are recovered by hand from gastric fluid aspirates and the stool of preterm infants hospitalized in a neonatal intensive care unit. In this case, digestive fluids are not always directly available to scientists and a technical procedure has been designed to avoid delays. First, digestive fluids have to be kept at room temperature and away from direct sun light to preserve cell viability, preferably for no more than $20 \mathrm{~min}$. Then samples are stored directly at $-70^{\circ} \mathrm{C}$ or snap frozen using liquid nitrogen. Storage at $4{ }^{\circ} \mathrm{C}$ or at $-20^{\circ} \mathrm{C}$ does not provide good results $\left(\right.$ at $-20^{\circ} \mathrm{C}$ ) probably due to the formation of ice crystal with deleterious effects on the thawing of cell structures. The one-hour transportation problem can also be overcome by immersing gastric aspirates or stool in Dulbecco's growth medium supplemented with D-glucose and L-glutamine, ${ }^{3}$ although the loss of pertinent chronobiological information may be considerable under these conditions of conservation.

Centrifugation is the best method for obtaining pellets of cellular materials from biological fluids devoid of large aggregates or mucus, such as urine for a urocytogram 47 or by gently swabbing oral mucosa on inner side of the cheek with a cytobrush to study cytogenetic damage. ${ }^{42}$ Manual exfoliation of the cells is also accomplished by applying the edge of a glass slide to the exposed surface of the open mucosa, as with colon resection specimens, and gently scraping. 30,50 The viability of cells recovered using this exfoliation/enrichment method or other similar techniques tends to lie between 90 to $100 \%$ according to the Trypan blue exclusion assay. There is a need for a device that recovers surface exfoliated cells of human rectal mucosa using minimal invasive scraping. 51

Magnetic beads and antibodies are known to recover low numbers of epithelial cells in biological fluids or to recover highly purified epithelial phenotypes. Antibodies against human cell surface antigens, such as AntiHep,3,52 from an original antibody, as described by Moldenhaus et al.,53 or anti-BerEp430,48 from an original antibody, as described by Sheibani et al., 54 labeled with paramagnetic particles, can be used to capture and to purify epithelial cells. However, in our experience, shieving is needed to perform immunocapture. With samples containing sheets of 5 to 30 cells, shieving or Percoll gradients are not appropriate, as the precious cellular material is discarded by the purification process. In addition, microbial contaminations are not easily removed by such density gradient methods, as microbes are closely associated with cells. Even with the manual exfoliation technique described by Mojica et al.30; the exfoliated cell populations may contain other cell types, most notably lymphocytes and plasma cells. It should be stressed that the problem of cross-contamination by other sources of exfoliated epithelial cells, such as the contamination of breast cells from milk with the gastric cells of lactating infants or of exfoliated cells by instruments, is particularly difficult to avoid, pointing to a need to develop biomarkers of tissue origin which can identify the origin of the cells in a cost-effective manner.

Our current studies demonstrate that a sufficient number of exfoliated cells can be recovered from gastric aspirates in preterm infants to measure the expression of specific genes of interest but the recovery of epithelial cells form stools is very inefficient. ${ }^{3}$ Exfoliated cells are shed in abundance in the stools of adult patients with colorectal cancer. These cells are non-apoptotic, and markers in exfoliated cells originating from the tumor are used for cancer screening and prevention.55,56 Exfoliated colonocytes are rare in human adults free of colorectal cancer as these cells are believed to be rapidly removed from colonic epithelium by phagocytosis. ${ }^{26,31}$ (Figure 1) Furthermore, these cells may be mixed with well-preserved squamous epithelial cells mechanically sloughed in abundance from the surface of the anal canal epithelium during every stool passage. According to Loktionov, 31 few colonocytes can be usually obtained in this way, whereas squamous cells of the anal canal epithelium often dominate the pool of isolated cells. Direct observation of colon cells recovered from preterm infants have not taken this possibility into account 3 and more studies are needed to design a phenotyping 
strategy that enables clear identification of colonocytes and squamous cells from the anal canal.

Exfoliated cells are studied using fixed cell immunofluorescent imaging, proteomics or transcriptomics (microarray technology). The methodology for recovering exfoliated cells is difficult to standardize and relies heavily on a cytological approach to minimize misinterpretations arising from microbial contamination or the presence of cells of different origin. Single-cell methods provide important information on the mean and variance of cell responses, but allow far fewer signals to be measured than is the case with proteomics or transcriptomics. ${ }^{57}$ Direct measurement using fluorospectrometry on live purified cell preparations would be provide valuable information, as normal tissue or diseased tissue (inflammation or cancer) produce distinctive spectra in vivo. Fluorescent profiles are caused by nicotinamide adenine dinucleotide (NADH), tryptophane, tyrosine and may help to outline the physiology of the epithelial cells. Profiles of normal gastric mucosa have been reported by Silveira et al.,58 although, after sampling, the fluorescence profiles of tissue biopsies are rapidly lost. Furthermore, spectral analysis of freshly isolated exfoliated epithelial cells remains unreported, probably because of the low numbers of exfoliated cells obtained and the sensitivity of the instruments.

\section{Microscopic analyses}

Microscopic examinations overcome the problems related to the heterogeneity inherent in working with clinical material by relating all results to the single cell. Exfoliated epithelial cells were described more than 50 years ago - as colonocytes 59 or urothelial cells 46,47 - but such descriptions were based on the microscopic examination of cell morphology and were of little use in characterizing the cellular origin of recovered cell phenotypes. In addition, dark material, such as fecal samples, may have adverse effects on direct examination, as well as heavy loads of autofluorescent materials, such as biliary salts. Cell enumeration by microscopic examination is a tedious and slow process but it makes it possible to easily distinguish quiescent from apoptotic cells $3,32,52$ and to evaluate not only contamination by yeasts and bacteria, but also the interactions with gastric cells when using milk supplemented with probiotics.

\section{Transcripts}

Studies to evaluate the Ribonucleic Acid (RNA) quality of postmortem human brain tissue indicate that ribosomal and messenger RNA have different degrees of degradation depending on postmortem conditions and extraction procedures. ${ }^{60}$ In similar studies, the isolation of total useful RNA in a Realtime Reverse Transcription-Polimerase Chain Reaction (RT-PCR) has been described for exfoliated human colonocytes recovered in exsudates during routine colonoscopy 41 or from stool.61 Stool is a hostile environment for biologically active molecules, such as messenger RNA, because of the presence of many naturally-produced chemicals, enzymes, and pigments. Many protocols have been proposed to isolate intact sloughed-off colonocytes from freshly passed stools, with most authors proposing to limit the processing of samples to less than $20 \mathrm{~min}$ subsequent to removal from their normal environment. The methodologies for preparing total RNA are based on commercially available kits, in order to reduce the chances of contaminating the preparations with degrading nucleases. In short, a standard procedure is to extract RNA within a very short period of time after collecting samples (stool or tissue), i. e., within 15 minutes. Recovery of intact but rare RNA molecules has been widely facilitated by the use of kits based on the amplification procedure of Phillips and Eberwine. 62 Likewise, detection of clock transcripts has been reported in exfoliated gastric and colonic cells of preterm infants. ${ }^{3}$ Future studies using exfoliated human cells may be able to employ the strategy used by Loboda et al.63 to compare diurnal variation of adipose transcriptome in silico, using the publiclyavailable Connectivity Map.

\section{Proteins}

Comparative proteomic analysis between scrapings of the human intestinal epithelium and colon cancer cell lines has revealed that numerous proteins can be used to profile both scrapings and cell lines. ${ }^{64}$ Vimentin (P08670) has been strongly associated with the differentiation process on 2D gels, suggesting that this protein can be used to counter normalization problems associated with quantification of clock components in epithelial cells of unknown origin. Beta-actin (P60709) is also useful to include in the normalization matrix, in view of its abundance and ubiquity. Of the circadian regulated proteins, alpha-enolase (P06733) was systematically detected by Lenaerts et al.,64 in scrapings from the large intestine. In the case of exfoliated cells from the cervix, Steinau et al. 43 have found that around $80 \%$ of genes are expressed in exfoliated cells compared to the total cell extract of a single corresponding tissue used as reference. Global proteomics has also been used to explore the difference between 
exfoliated breast cells. ${ }^{39}$ Normalization remains hazardous, as the quantity of cellular material is often very low and frequently below the present levels of detection using 2-D gel electrophoresis. Up to now, global proteomics has been of little use in analyzing exfoliated cells, in view of the difficulties encountered with proper labeling of cell populations that are frequently below 1,000 . Such a labeling technique on 1,000 cells has been described by Sitek et al. 65 and involves performing fluorescence dye saturation labeling in combination with high resolution two-dimensional gel electrophoresis, but the methodology has not yet been applied to exfoliated cells. Reddy et al. ${ }^{66}$ pooled the livers of six mice to obtain reliable results regarding the circadian rhythm of hepatocyte proteomes using two-dimensional difference gel electrophoresis. Again current animal models may help to circumvent the problem of the scarcity of reference materials as well as to allow efficient pooling of exfoliated epithelial cells.

\section{DNA and associated histones of the regulatory} transcription complex

Ways of monitoring exfoliation of host DNA have been designed for genomic studies on the total DNA of human breast epithelial cells 40 or using Real-time PCR of host DNA in human or rat colonocytes. 26 In the field of epigenetics, clock and parental imprinting have been found to be connected, as Magel2 is imprinted in the male genome and regulates normal circadian output. 67 This information may be accessible in the exfoliated epithelial cell genome.

Histone acetylation has not been explored in exfoliated cells but it constitutes a future field of active investigation. Histone acetylation has been linked to the acquisition of epigenetic profiles during normal development or following perinatal denutritition and can be directly evaluated using the histone acetyltransferase activity harbored by CLOCK. 68 Methodologies to check all these parameters will be crucial for broadening the usefulness of exfoliated epithelial cells in chronobiology as well as in physiology. Finally, with a low potential for measuring chronobiological parameters but widely used in genotoxic studies, the formation of micronuclei in exfoliated cells, which emerge during mitosis of the basal layers of the epithelium from different organs (like oral and nasal cavity, bladder, cervix and esophagus), has been used as an end point to detect exposure to genotoxins or bioactive food components. $42,69,70$

In short, the problem with the recovery of exfoliated cells is that of relating these cells to the intact tissue structure of the donor. The degradation of biological information depends on the bioactive compounds present in the biological fluids, which may be heavily loaded with enzymes, such as digestive fluids. The availability of animal models is of paramount importance in developing in vivo studies of anoikis and its connection with molecular circadian clocks as a way of evaluating the stability of chronobiological molecular information in exfoliated cells.

Stability of chronobiological information in exfoliated epithelial cells

The chronobiological information that can be extracted from exfoliated epithelial cells depends on the techniques used to isolate cellular material or the manipulation of physiological parameters (Figure 1) and on the affinity of interactions of clock molecular components with stable molecules, such as DNA or the persistence of the physiological effects that they induce. Cells have to process diverse signals such as temperature, $\mathrm{pH}$, and nutrient concentrations in order to maintain a normal physiology. In vivo, cells are believed to use clocks to organize and adapt cellular metabolisms and coordinate three-dimensional macromolecular organization (their phenotype) in a noisy molecular environment (molecular signals criss-crossing within and between cells and irrelevant chemical messages). This process has been formalized by Tan et al.71 in a genetic model that is useful for understanding signal processing and the influence of cellular noise on the reliability and speed of frequency-signal transmission. Exfoliated epithelial cells in anoikis can be seen as a way of obtaining chronobiological information dating back from the time the cells peeled from the surface of the functional unit. According to the mathematical model of Tan et al., ${ }^{71}$ relevant biological information can be encoded in the amplitude or the frequency domains of a signal. Signals encoded in the amplitude domain are predominantly based on concentrations of signaling molecules, a parameter difficult to measure in exfoliated cells in anoikis without proper normalization at the single cell level in highly purified cell phenotypes. In addition, some highly labile biochemical modifications, such as phosphorylation, are probably lost during the storage of biological fluids and in the isolation process or can be made irrelevant to the pathophysiology of the mucosa due to the turn-over of the signal by the cellular machinery. However according to Gallego and Virshup, 72 the addition of phosphatase inhibitors to cell extracts can preserve period proteins. 
Significant improvements in the quality of cell extracts may be achieved using extraction bufffers suitable for preserving clock gene products. The biological information encoded in the frequency domain of an oscillatory signal can be transmitted as concatenated signals with multiple biologically significant signals to gene behind the regulatory sequence within the promoter. In transgenic mammals, oscillations can be measured by recording rhythms of light emissions by cells in which the promoter of some clock gene is linked to a luciferase reporter. In humans or non-transgenic mammals, oscillations per se cannot be measured in the absence of spectrofluorimetric methods applicable on freshly recovered living cells but indirect evidence of genecircuit activation may be recovered. Long-lasting or resilient information may be accessible either: a) by way of the machinery of transcription at the site of fixation on the DNA of the cells or b) using the histone code, as these epigenetic modifications are believed to be acquired with a stability related to the original tissue 73 and to the time of day. 74

We may speculate that quiescent cells, such as epithelial gastric cells, retain fully functional clocks i. e. consistent information with their time at exfoliation and subsequent cell survival outside the organism. The induction of gastric cell exfoliation by the nutrient cycle developed in rats by Aoyama et al. 24 that we have adapted to lactating rat pups 32 could be used in the future to address questions regarding the stability of clock information during anoikis. Exfoliated epithelial cells can be followed by microscopic examination from the initial step of loss of contact at the mouth of the gastric gland to the recovery of cells in the stomach lumen. In addition, the model is clearly relevant to clinical situations in which patients are equipped with nasogastric tubing. However, there may be tissue-specific differences in the molecular composition of the circadian clock, and clock components that have subtle effects on the central clock function may play a more prominent role in the regulation of peripheral clocks. Yagita et al., ${ }^{75}$ have used spontaneously immortalized mouse embryo fibroblasts to explore the main clock components (proteins and mRNA) suggesting that peripheral clocks in cultured cells may be similar in composition and regulation as the central clock, but all these components are not always present in cells, depending on their tissue origin. The most striking example is the apparent redundancy of the clock in relation to its homolog, npas2, the two being largely equivalent molecules with strict structural differences.76,77 Exfoliated epithelial cells, after losing contact with the extracellular matrix survive by activating autophagy. Three main physiological pathways have been described associated with the regulation of autophagy: AKT (energysensing), EGR-R (growth factor-sensing) and bcl-2 (stress-related programmed-cell death). According to Gan et al.,78 mTOR downregulation is also observed subsequent to extracellular matrix detachment. Clock components are probably also altered during this process but there are no data on the relation between autophagy and clock regulation.

By contrast, explants of tissue isolated from transgenic rats for the period 1 gene provide some chronobiological information about the chaotic expression of this gene under the drastic external conditions of explantation. ${ }^{79}$ Records of the luminescence emitted in vitro by explants maintained in classic tissue culture conditions $\left(37^{\circ} \mathrm{C}, 5 \% \mathrm{CO}_{2}\right)$ have clearly shown that the chaotic light emissions from the transgene system continue for 12-14 hours and that, thereafter, the rhythms of light emissions from liver explants are organized according to an oscillatory model reminiscent of period 1 's in vivo oscillations (as described in Stokkan et al.79) The phase of the peak has been recorded during the first subjective day in culture i. e. between 12 and 36 hours, in order to compare explants from rats maintained on ad libitum feeding with rats on restricted feeding. To avoid such chaotic evolution with the loss of chronobiological information, experimenters use mechanical mucosal punches, which are immediately snap frozen in liquid nitrogen. This strategy is a reliable but invasive solution for studying clock gene expression in time series. Otherwise, tissue biopsies can be explanted in culture to derive primary cells or cell lines and record clock functioning in exactly the same way as with exfoliated cells. However, cell lines have lost contact with body's network and their clock systems are probably quickly reorganized to attune to their new in vitro environment. 80,81

In short, clock-related information has not yet been extensively studied in exfoliated cells. Recent data on the molecular biology of clock components indicate that central and peripheral clocks differ in their coupling with the different categories of synchronizers as well as in their output in rodent models 82 as well as in human data. ${ }^{72}$ Future studies could employ epigenetic tags to delineate the onset of acquisition of a stable epigenetic profile as a way of exploring clock gene regulation in peripheral organs. 


\section{Perspectives}

The development of non-invasive methods is crucial in that it allows for easy sampling of human populations for nutritional/clinical intervention studies. The possibility that subtle environmental influences during development cause persistent changes in epigenetic regulation may be of critical public health importance in the prevention of metabolic syndrome. 73

A specific application would be to develop studies of exfoliation in order to improve nursing care in preterm infants and to prevent the onset of such a syndrome during adult life. The isolation of exfoliated epithelial cells from pups or infants suffering from perinatal denutrition at the onset of the problem or later in adult life may help to determine whether the histone acetyltransferase activity of CLOCK can be used to explore the stability of epigenetic profile in exfoliated epithelial cells.

Up to now, the liver has been the organ of choice when studying peripheral clock functioning, but a better understanding of circadian rhythms requires the inclusion of information from complex tissue architectures, such as the lungs or the gut, which are at the interface with the external environment. An analysis of exfoliated epithelial cells to determine

\section{References}

1. Davis CD. Use of exfoliated cells from target tissues to predict responses to bioactive food components. J Nutr. 2003; 133: 1769-72.

2. Kamra A, Kessie G, Chen JH, Kalavapudi S, Shores R, McElroy I, Gireesh T, Sudhakaran PR, Dutta SK, Nair PP. Exfoliated colonic epithelial cells: surrogate targets for evaluation of bioactive food components in cancer prevention. J Nutr. 2005; 11: 2719-22.

3. Kaeffer B, Des Robert C, Alexandre-Gouabau MC, Pagnièz A, Amarger V, Legrand A, Küster A, Piloquet H, Champ M, Le Huërou-Luron I, Rozé J-C. Recovery of exfoliated cells from the gastro-intestinal tract of premature infants: a new tool to obtain "non-invasive biopsies"? Pediatr Res. 2007; 62: 564-9.

4. Touitou Y, Haus E. Biological rhythms in clinical and laboratory medicine. Berlin: Springer-Vrelag; 1992.

5. Ticher A, Ashkenazi IE, Reinberg A. Preservation of the functional advantage of human time structure. FASEB J. 1995; 9: 169-272.

6. Reinberg AE. Chronobiologie médicale, chronothérapeutique. Paris: Médecine-Sciences Flammarion; 2003. 298 p.

7. Moore-Ede MC. Physiology of the circadian timing system: predictive versus reactive homeostasis. Am J Physiol. 1986; 250: R735-52. proportions of cells in anoikis can be rapidly achieved by direct examination of nucleus integrity and relevant cell populations may be purified using antibody methods. Unique data on the coupling/decoupling capacity of peripheral clocks may be obtained from long-term experiments by combining the recovery of low cell numbers with analytical cytology and microarray technologies. However there is a lack of biomarkers for studying exfoliated epithelial cells and the role of clock genes, if any, in autophagy. Among many unsolved questions is that of the exact nature of the biological information retained, altered or lost during anoikis. Future studies could focus on the mTOR signaling pathway, which has been found to be down-regulated in detached epithelial cells 78 and, in adipocytes, a process that is related to diurnal gene expression and metabolic regulation. 63

\section{Acknowledgements}

This review was given in part during the "XVII Simpósio sobre o cérebro, Centro de Ciências da Saúde. A evolução do cérebro", November 2009, Universidade Federal de Pernambuco, Recife with the help of Capes - Cofecub funding (Me 657/09).

8. Bjarnason GA, Jordan RCK, Wood PA, Li Q, Lincoln DW, Sothern RB, Hrushesky WJM, Ben-David Y. Circadian expression of clock genes in human oral mucosa and skin. Association with specific cell-cycle phases. Am J Pathol. 2001; 158: 1793-801.

9. Zanello SB, Jackson DM, Holick MF. Expression of the circadian clock genes clock and period1 in human skin. J Invest Dermatol. 2000; 115: 757-60.

10. Pardini L, Kaeffer B, Trubuil A, Bourreille A, Galmiche JP. Human intestinal circadian clock: expression of clock genes in colonocytes lining the crypt. Chronobiol Int. 2005; 6: 951-61.

11. Lock R, Debnath J. Extracellular matrix regulation of autophagy. Cur Opin Cell Biol. 2008; 20: 583-8.

12. Karam SM. Lineage commitment and maturation of epithelial cells in the gut. Front Biosci. 1999; 4: 286-98.

13. Kaeffer B. Mammalian intestinal epithelium cells in primary culture: a mini review. In vitro Cell Dev Biol Anim. 2002; 38: 123-34.

14. Potten CS, Loeffler M. Stem cells attributes, cycles spirals, pitfalls and uncertainties-lessons for and from the crypt. Development. 1990; 110: 1001-20. 
15. Qiu JM, Roberts SA, Potten CS. Cell migration in the small and large bowel shows a strong circadian rhythm. Epithelial Cell Biol. 1994; 3: 137-48.

16. Buchi KN, Moore JG, Hrushesky WJM, Sothern RB, Rubin NH. Circadian rhythm of cellular proliferation in the human rectal mucosa. Gastroenterol. 1991; 101: 410-5.

17. Marra G, Anti M, Percesepe A, Armelao F, Ficarelli R, Coco C, Rinelli A, Vecchio FM, D'Arcangelo E. Circadian variations of epithelial cell proliferation in human rectal crypts. Gastroenterol. 1994; 106: 982-7.

18. Iwakiri R, Gotoh Y, Noda T, Sugihara H, Fujimoto K, Fuseler J, Aw TY. Programmed cell death in rat intestine: effect of feeding and fasting. Scand J Gastroenterol. 2001; 36: 39-47.

19. Matsuo T, Yamaguchi S, Mitsui S, Emi A, Shimoda F, Okamura H. Control mechanism of the circadian clock for timing of cell division in vivo. Science. 2003; 302: 255-9.

20. Polidarová L, Soták M, Sládek M, Pácha J, Sumová A. Temporal Gradient in the Clock Gene and Cell-Cycle Checkpoint Kinase Wee1 Expression along the Gut. Chronobiol Int. 2009; 26: 607-20.

21. Haus E, Lakatua DJ, Sackett-Lundeen L, White M. Circannual variation of intestinal cell proliferation in BDF1 male mice on three lighting regimens. Chronobiol Int. 1984; 1: 185-94.

22. Gomes JR, Pereira AAM, Barth L, Silva JS, Leite ML, Wille ACM, Soares MAM. Circadian variation of the cell proliferation in the jejunal epithelium of rats at weaning phase. Cell Prolif. 2005; 38: 147-52.

23. Kitazawa H, Nishihara T, Nambu T, Nishzawa H, Iwaki M, Fukuhara A, Kitamura T, Matsuda M, Shimomura I. Intectin, a novel small intestine-specific glycosylphosphatidylinositol-anchored protein, accelerates apoptosis of intestinal epithelial cells. J Biol Chem. 2004; 279: 4286774.

24. Aoyama F, Sawaguchi A, Ide S, Kitamura K, Suganuma T. Exfoliation of gastric pit-parietal cells into the gastric lumen associated with a stimulation of isolated rat gastric mucosa in vitro: a morphological study by the application of cryotechniques. Histochem Cell Biol. 2008; 129: 78593.

25. Frisch SM, Francis H. Disruption of epithelial cell-matrix interactions induces apoptosis. J Cell Biol. 1994; 124: 61926.

26. Van Lieshout EM, Van Doesburg W, Van der Meer R. Realtime PCR of host DNA in feces to study differential exfoliation of colonocytes between rats and humans. Scand J Gastroenterol. 2004; 39: 852-7.

27. Abizaid A, Mezei G, Sotonyi P, Horvath TL. Sex differences in adult suprachiamastic nucleus neurons emerging late prenatally in rats. Eur J Neurosci. 2004; 19: 2488-90.

28. Carskadon MA, Wolfson AR, Acebo C, Tzischinsky O, Seifer R. Adolescent sleep patterns, circadian timing, and sleepiness at a transition to early school days. Sleep. 1998; 21: $871-81$

29. Rivkees SA. Developing circadian rhythmicity in infants. Pediatrics. 2003; 112: 373-81.

30. Mojica WD, Stein L, Hawthorn L. An exfoliation and enrichment strategy results in improved transcriptional profiles when compared to matched formalin fixed samples.
BMC Clin Pathol. 2007; 7:7 doi 10.1186/1472-6890/7/7

31.Loktionov A. Cell exfoliation in the human colon: myth, reality and implications for colorectal cancer screening. Int J Cancer. 2007; 120: 2281-9.

32. Kaeffer B, Qi H, Matos RJB, Legrand A, Chauty A, Darmaun D, Morel F, Gouthière L, Bolanos-Jimenez F, Champ M, Rozé J-C. Exfoliated epithelial cells, a source of information on clock genes expression by preterm infants to explore the onset of metabolic syndrome. Proceedings of the XI Congress of the European Biological Rhythms Society; 2009, Aug 22-28; Strasbourg.

33. Gilemore AP. Anoikis. Cell Death Differ. 2005; 12 (suppl 2): 1473-7.

34. Yan SR, Joseph RR, Rosen K, Reginato MJ, Jackson A, Allaire N, Brugge JS, Jobin C, Stadnyk AW. Activation of NF-kappa B following detachment delays apoptosis in intestinal epithelial cells. Oncogene. 2005; 24: 6482-91.

35. Liu Z, Li H, Wu X, Yoo BH, Yan SR, Stadnyk AW, Sasazuki T, Shirasawa S, LaCasse EC, Korneluk RG, Rosen KV. Detachment-induced upregulation of XIAP and cIAP2 delays anoikis of intestinal epithelial cells. Oncogene. 2006; 25: 7680-90.

36. Debnath J, Mills KR, Collins NL, Reginato MJ, Muthuswamy SK, Brugge JS. The role of apoptosis in creating and maintaining luminal space within normal and oncogene-expressing mammary acini. Cell. 2002; 111: 2940.

37. Fung C, Lock R, Gao S, Salas E, Debnath J. Induction of autophagy during extracellular matrix detachment promotes cell survival. Mol Biol Cell. 2008; 19: 797-806.

38. Levine B and Klionsky DJ. Development by self-digestion: molecular mechanisms and biological functions of autophagy. Dev Cell. 2004; 6: 463-77.

39. Klein P, Glaser E, Grogan L, Keane L, Lipkowitz S, Sobalie P, Brooks L, Jenkins J, Steinberg SM, DeMarini DM, Kirsch I. Biomarker assays in nipple aspirate fluid. Breast J. 2001; 7: 378-87.

40. Thompson PA, Kadlubar FF, Vena SM, Hill HL, McClure GHY, McDaniel LP, Ambrosone CB. Exfoliated ductal epithelial cells in human breast milk: a source of target tissue DNA for molecular epidemiologic studies of breast cancer. Cancer Epidemiol Biomarkers Prev. 1998; 7: 37-42.

41. Davidson LA, Lupton JR, Miskovsky E, Fields AP, Chapkin RS. Quantification of human intestinal gene expression profiles using exfoliated colonocytes: a pilot study. Biomarkers. 2003; 8: 51-61.

42. Holland N, Harmatz P, Golden D, Hubbard A, Wu YY, Bae J, Chen C, Huen K, Heyman MB. Cytogenetic damages in blood lymphocytes and exfoliated epithelial cells of children with inflammatory bowel disease. Pediatr Res. 2007; 61: 1-6.

43. Steinau M, Lee DR, Rajeevan MS, Vernon SD, Ruffin MT, Unger ER. Gene expression profile of cervical tissue compared to exfoliated cells: impact on biomarker discovery. BMC Genomics. 2005; 6: 64. Available in: http://www.biomedcentral.com/1471-2164/6/64/abstract/

44. Stitch HF, Stitch W, Rosin MP, Vallejara MO. (). Use of the micronucleus test to monitor the effect of Vitamin A, betacarotene and canthaxanthin on the buccal mucosa of betel nut/tobacco chewers. Int J Cancer. 1984; 34: 745-50. 
45. Munoz N, Hayashi M, Bang LJ, Wahrendorf J, Crespi M, Bosch FX. Effect of riboflavin, retinol and zinc on micronulei of buccal mucosa and of esophagus: a randomized double-blind intervention study in China. J Natl Cancer Inst. 1987; 79: 687-91.

46. Felix JS. Human newborn urine as a source of epithelial cells. Birth defects 1980. 16: 85-93.

47. Robine N, Relier JP, Le Bars S. Urocytogram, an index of maturity in premature infants. Biol Neonate. 1988; 54: 93-

48. Mojica WD, Rapkiewicz AV, Liotta LA, Espina V. Manual exfoliation of fresh tissue obviates the need for frozen sections for molecular profiling. Cancer Cytopathol. 2005; 105: 483-91.

49. Portaluppi F, Touitou Y, Smolensky MH. Ethical and methodological standards for laboratory and medical biological rhythm research. Chronobiol Int. 2008; 25: 9991016.

50. Yang GC, Hoda SA. (). Combined use of the "Scratch and Smear" sampling technique and ultrafast Papanicolaou stain for intraoperative cytology. Acad Cytol. 1997; 41: 1513-8.

51. Loktionov A., Bandatelova T, Llewelyn A, Ferrett C, Lywood RCG, Lywood HGG. (). Colorectal cell sampling device. World Intellectual Property Organisation. International Publication Number WO 2006/003447 A1; 2006.

52. Bandaletova T, Bailey N, Bingham SA, Loktionov A. Isolation of exfoliated colonocytes from human stools as a new technique for colonic cytology. APMIS. 2002; 110 : 239-46.

53. Moldenhauer G, Momburg F, Möller P, Schwartz R, Hämmerling GJ. () Epithelium-specific surface glycoprotein of $\mathrm{Mr} 34,000$ is a widely distributed human carcinoma marker. Br J Cancer. 1987; 56: 714-21.

54. Sheibani K, Shin SS, Kezirian J, Weiss LM. Ber-Ep4 antibody as a discriminant in the differential diagnosis of malignant mesothelioma versus adenocarcinoma. Am J Surg Pathol. 1991; 15: 779-84.

55. Albaugh, GP, Iyengar V, Lohani A, Malayeri M, Bala S, Nair PP. Isolation of exfoliated colonic epithelial cells, a novel non-invasive approach to the study of cellular markers. Int J Cancer. 1992; 52: 347-50.

56. Osborn NK, Ahlquist DA. Stool screening for colorectal cancer: molecular approaches. Gastroenterol. 2005; 128: 192-206.

57. Albeck JG, MacBeath G, White FM, Sorger PK, Lauffenburger DA, Gaudet S. Collecting and organizing systematic sets of protein data. Nat Rev Mol Cell Biol. 2006; 7: 803-12.

58. Silveira Jr L, Betiol Filho JA, Silveira FL, Zângaro RA, Pacheco MTT. Laser-induced fluorescence at $488 \mathrm{~nm}$ excitation for detecting benign and malignant lesions in stomach mucosa. J Fluoresc. 20081; 8: 35-40

59. Bader GM, Papanicolaou GN. The application of cytology in the diagnosis of cancer of the rectum, sigmoid, and descending colon. Cancer. 1952; 5: 307-14

60. Miller CL, Diglisic S, Leister F, Webster M, Yolken RH. Evaluating RNA status for RT-PCR in extracts of post- mortem human brain tissue. Biotechniques. 2004; 36: 62833.

61. Ahmed FE, James SI, Lysle DT, Dobbs JR LJ, Johnke RM, Flake G, Stockton P, Sinar DR, Naziri W, Evans MJ, Kovacs CJ, Allison RR. Improved methods for extracting RNA from exfoliated human colonocytes in stool and RT-PCR analysis. Dig Dis Sci. 2004; 49: 1889-98.

62. Phillips J, Eberwine JH. Antisense RNA amplification: a linear amplification method for analyzing the mRNA population from single living cells. Methods. 1996; 10: 283-8.

63. Loboda A, Kraft WK, Fine B, Joseph J, Nebozhyn M, Zhang C, He Y, Yang X, Wright C, Morris M, Chalikonda I, Ferguson M, Emilsson V, Leonardson A, Lamb J, Dai H, Schadt E, Greenberg HE, Lum PY. Diurnal variation of the human adipose transcriptome and the link to metabolic disease. BMC Med Genomics. 2009; 2:7. Available in: http://www.biomedcentral.com/1755-8794/2/7

64. Lenaerts K, Bouwman FG, Lamers WH, Renes J, Mariman EC. Comparative proteomic analysis of cell lines and scrapings of the human intestinal epithelium. BMC Genomics. 2007; 8: 91 doi: 10.1186/1471-2164/8/91

65. Sitek B, Sipos B, Klöppel G, Schmiegel W, Hahn SA, Meyer HE, Stühler K. Application of fluorescence dye saturation labeling for differential proteome analysis of 1,000 microdissected cells from pancreatic ductal adenocarcinoma precursor lesions. Methods Mol Biol. 2008; 425: 114.

66. Reddy AB, Karp NA, Maywood ES, Sage EA, Deery M, O'Neill JS, Wong JKY, Chesham J, Odell M, Lilley KS, Kyriacou CP, Hasting MH. Circadian Orchestration of the Hepatic Proteome. Curr Biol. 2006; 16: 1107-15.

67. Kozlov SV, Bogenpohl JW, Howell MP, Wevrick R, Panda S, Hogenesch JB, Muglia LJ, Van Gelder RN, Herzog ED, Stewart C. The imprinted gene Magel2 regulates normal circadian output. Nat Genet. 2007; 39: 1266-72.

68. Doi M, Hirayama J, Sassone-Corsi P. Circadian regulator CLOCK is a histone acetyltransferase. Cell. 2006; 125 : 424-6.

69. Fenech M, Holland N, Chang WP, Zeiger E, Bonassi S. The HUMN project: an international colloborative study on the use of the micronucleus technique for measuring DNA damage in humans. Mutat Res. 1999; 428: 271-83.

70. Majer BJ, Laky B, Knasmuller S, Kassie F. Use of the micronucleus assay with exfoliated epithelial cells as a biomarker for monitoring individuals at elevated risk of genetic damage and in chemoprevention trials. Mutat Res. 2001; 489: 147-72.

71. Tan C, Reza F, You L. Noise-limited frequency signal transmission in gene circuits. Biophys J. 2007; 93: 3753-61.

72. Gallego M, Virshup DM. Post-translational modifications regulate the ticking of the circadian clock. Nat Rev Mol Cell Biol. 2007; 8: 139-48.

73. Waterland RA, Michels KB. Epigenetic epidemiology of the developmental origins hypothesis. Annu Rev Nutr. 2007; 27: 363-88.

74. Alenghat T, Meyers K, Mullican SE, Leitner K, AdenijiAdele A, Avila J, Bucan M, Ahima R, Kaestner KH, Lazar MA. Nuclear receptor corepressor and histone deacetylase 3 govern circadian metabolic physiology. Nature. 2008; 456: $997-1001$. 
75. Yagita K, Tamanini F, van der Horst G, Okamura $H$. Molecular mecanisms of the biological clock in cultured fibroblasts. Science. 2001; 292: 278-81.

76. Reick M, Garcia JA, Dudley C, McKnight SL. NPAS2: an analog of Clock operative in the mammalian forebrain. Science. 2001; 293: 506-9.

77. Rutter J, Reick M., Wu LC, McKnight SL. Regulation of Clock and NPAS2 DNA binding by the Redox state of NAD cofactors. Science. 2001; 293: 510-4.

78. Gan B, Yoo Y, Guan JL. Association of focal adhesion kinase with tuberous sclerosis complex 2 in the regulation of s6 kinase activation and cell growth. J Biol Chem. 2006; 281: 37321-9

79. Stokkan K-A, Yamazaki S, Tei H, Sakaki Y, Menaker M. Entrainment of the circadian clock in the liver by feeding. Science. 2001; 291: 490-3.

Recebido em 4 de janeiro de 2010

Aprovado em 18 de janeiro de 2010
80. Nagoshi E, Saini C, Bauer C, Laroche T, Naef F, Schibler U. Circadian gene expression in individual fibroblasts: cellautonomous and self-sustained oscillators pass time to daughter cells. Cell. 2004; 119: 693-705.

81. Brown SA, Fleury-Olela F, Nagoshi E, Hauser C, Juge C, Meier CA, Chicheportiche R, Dayer J-M, Schibler U. The Period length of fibroblast circadian gene expression varies widely among human individuals. PLOS Biol. 2005; 3 : 1813-8.

82. Sumova A, Bendova Z, Sladek M, El-Hennamy R, Laurinova K, Jindrakova Z, Illnerova H. Setting the biological time in central and peripheral clocks during ontogenesis. FEBS Letters. 2006; 580: 2836-42. 